Diversity and Direction in Psychoanalytic Technique 
This page intentionally left blank 


\title{
Diversity and Direction in Psychoanalytic Technique
}

\author{
Fred Pine
}

Yale University Press New Haven \& London 
Copyright (C) 1998 by Rachael Pine and Daniel Pine. All rights reserved. This book may not be reproduced, in whole or in part, including illustrations, in any form (beyond that copying permitted by Sections 107 and 108 of the U.S. Copyright Law and except by reviewers for the public press), without written permission from the publishers.

Designed by Rebecca Gibb. Set in Minion type by Keystone Typesetting, Inc., Orwigsburg,Pennsylvania. Printed in the United States of America by Vail-Ballou Press, Binghamton, New York.

Library of Congress Cataloging-in-Publication Data

Pine, Fred, 1931-

Diversity and direction in psychoanalytic technique / Fred Pine.

p. $\mathrm{cm}$.

Includes bibliographical references and index.

ISBN 0-300-07344-5 (hardcover : alk. paper)

1. Psychoanalysis. I. Title.

$\mathrm{RC}_{504 . P_{558}} 1997$

$616.89^{\prime} 17-\mathrm{dc} 21$

97-37013 CIP

A catalogue record for this book is available from the British Library.

The paper in this book meets the guidelines for permanence and durability of the Committee on Production Guidelines for Book Longevity of the Council on Library Resources.

$\begin{array}{llllllllll}10 & 9 & 8 & 7 & 6 & 5 & 4 & 3 & 2 & 1\end{array}$ 
To Louis and Mollie

and to Harold and Beverly

lovingly 
This page intentionally left blank 